\title{
Analysis of Regional Financial Capability in Supporting the Implementation of Regional Autonomy in Pasangkayu Regency, West Sulawesi Province for the 2014-2018 Period
}

\author{
Taufik Hidayat B Tahawa ${ }^{1}$, Riady Ibnu Khaldun ${ }^{2}$ \\ \{taufikhidayat@unsulbar.ac.id, riadyibnu@unsulbar.ac.id\} \\ Faculty of Economic, Universitas Sulawesi Barat ${ }^{1}$, Faculty of Social and Political Sciences, \\ Universitas Sulawesi Barat ${ }^{2}$
}

\begin{abstract}
The purpose of this study was to analyze financial performance, analyze and analyze the government of Pasangkayu Regency in 2013-2018. This type of research is quantitative using secondary data and analyzed using financial ratios. The results of this study indicate that the analysis of variance has met the criteria where the income is greater than budgeted, the analysis of the degree of fiscal decentralization below 10 percent shows that it is still lacking. the analysis of the level of regional independence is still very low with a percentage below the criteria of 25 percent, the analysis of the variety of expenditures has mostly met the criteria, the regional revenue analysis shows the results of 2 periods and the analysis of regional financial efficiency for most of these periods is still below the criteria of efficiency with the proportion still exceeding 90 percent.
\end{abstract}

Keywords: Financial Performance, Analysis of Income Variants, Analysis of the Degree of Fiscal Decentralization, Analysis of the Level of Regional Independence, Analysis of Expenditure Variants, Analysis of the Effectiveness of Regional Original Income, Analysis of Regional Financial Efficiency

\section{Introduction}

Indonesia is the world's largest archipelagic country located in Southeast Asia by total number of 16.056 islands and also the world's most populous island country consisting of 34 provinces. This strategic geographical condition can potentially create benefits and also challenges in managing economic resources. In the Government Work Plan (RKP) for 2020 which is also a reference in the implementation of the National Medium-Term Development Plan (RPJMN), various efforts have been made until the fifth year of implementing the RPJMN for the 2020-2024 period to accelerate the main objectives contained in the national development priority agenda where one of the agendas is for medium-term planning, specifically "developing Indonesia from the periphery by strengthening regions and villages within the framework of a unitary state". To realize this program, it is necessary to carry out regional autonomy so that the potential possessed by Indonesia can be maximized and can be managed properly. The concept of regional autonomy emphasizes that regional governments obtain discretion from the central government to develop autonomous regions. This regional autonomy is created with the aim of helping the government process run more effectively. Autonomous regions are regions with the authority to regulate their own household affairs 
without the intervention of the central government [1]. Autonomous regions have absolute authority to explore regional potential including their own financial sources, regulate and use their own finances to finance their government.

Regional autonomy and decentralization policies are the main instruments in the governance of the implementation of national development. These policies provide the authorities for the autonomous regions (provinces, regencies and cities) to develop the area and provide better services to the community, because the community can easily reach the location of services provided in their area. The implementation of governance in the regions is also supported by the policy of financial transfers from the central government to the regions, with the amount of funds increasing from year to year. This provides opportunities for regions to grow and develop properly, quickly and optimally. The regulatory basis for implementing decentralization and regional autonomy is Law No. 23 of 2014 concerning Regional Government. However, in its implementation, many derivative laws have not been stipulated. In terms of the implementation of fiscal decentralization, Law Number 33 of 2004 concerning Financial Balance between the Central Government and Regional Governments and its derivative laws and regulations are still used as guidelines to this day.

Reform in the current government bureaucracy can be based on the implementation of regional autonomy. Regional Autonomy also has consequences for government elements to govern and administer the interest of the regional people according to its own initiatives based on the people's aspirations in accordance with the prevailing laws and regulations. In carrying out the regional autonomy, Regional Governments are required to run an effective and efficient government system, and must be able to support the role of society in increasing equity and justice by developing all the potential that the regions have. The potential of this area can be managed properly by using regional financial instruments that have been regulated in statutory regulations. The successful implemention of regional autonomy cannot be separated from the ability in financial instruments. Therefore, the regional governments are expected to develop their own regional potentials and explore existing sources of funds to realize the welfare of their people. The funding mechanism in implementing regional autonomy has changed over time. These changes require the regional autonomy to prioritize the potential for regional original revenue either through regional taxes, regional levies or the profits of Regional Owned Enterprises (BUMD) and other revenues that are considered legitimate as well as other potential revenues that are still not affordable by Regional Original Revenue (PAD). [2]

There are four important elements submitted by the Central Government to Regional Governments in the implementation of Regional Autonomy [3]. The four elements consist of Political Decentralization, Degree of Decentralization, Administrative Decentralization and Economic Decentralization. These elements become the obligation of the regions to manage efficiently and effectively. Regarding to this matter, the ability/independence of the region will be created in order to carry out its functions properly. In order to be more efficient and effective in terms of regional expenditure, a region is required to uphold accountability and justice. Besides that, the Regional Government is responsible for publishing financial reports to the stakeholders [4]. Based on Government Regulation Number 71 of 2010 concerning Government Accounting Standards, financial reports have the role of providing relevant information regarding financial positions and transactions during one reporting period. Regional government financial reports serve as a tool in the decision-making process. Therefore, financial reports must be presented in a simple and detailed manner, so that they are easily understood by those who need the information. In order to make financial reports easier to understand and interpret, financial report analysis assistance is needed. One of the measuring tools that can be 
used to analyze the regional performance in managing the regional finances is by analyzing the financial ratios. [5]

To find out the extent to which the level of regional financial capability presented in the financial reports, it is necessary to analyze the financial reports. The technique used to analyze financial reports is Financial Ratio Analysis. Financial Ratio Analysis is a measure to identify financial characteristics based on available financial reports [4]. The Financial Ratio Analysis to the Regional Revenue and Expenditure Budget (APBD) is carried out by calculating the Regional Financial Performance and Regional Financial Capability. There are several ways to calculate the Regional Financial Performance, including calculating the Revenue Variance Analysis, Fiscal Decentralization Degree Ratio, Regional Independence Ratio, Effectiveness Ratio, Expenditure Variance Ratio and Efficiency Ratio.

Revenue Variance Analysis is used to measure the budget performance by using the variance analysis of the Revenue budget. Variance analysis is done by evaluating the difference between budget and Revenue realization. The Fiscal Decentralization Degree Ratio illustrates the extent of central government intervention in regional development which shows the level of readiness of regional governments in implementing regional autonomy. This independence ratio will illustrate the level of regional dependence on external funding sources. The higher the independence ratio means that level of regional dependence on external assistance is getting lower. The ratio of PAD effectiveness shows the ability of regional governments to mobilize regional revenues according to budget. Expenditure variance analysis is used for budget performance assessment. Meanwhile, efficiency analysis is used to measure the maximum output achievement with certain inputs [6].

This study was conducted in Pasangkayu Regency, West Sulawesi Province. In order to realize the Vision of Pasangkayu Regency to be "Professional, Productive \& Proactive Pasangkayu in 2021", this study aimed to examine the financial capability of Pasangkayu Regency in achieving the vision and sustainable development. With regard to regional development policies, Law Number 25 of 2004 concerning the National Development Planning System (SPPN) mandates that the long term, medium term and annual development planning is carried out by elements of state administrators and society at the central and regional levels [7]. The following shows the data on the Realization of the Regional Revenue and Expenditure Budget of the Pasangkayu Regency Government from 2013 to 2018:

Table 1. Realization of Revenue and Expenditure in Pasangkayu Regency in 2013 - 2018

\begin{tabular}{cccc}
\hline \multirow{2}{*}{ Year } & \multicolumn{2}{c}{ Pasangkayu } & Revenue and expenditure \\
\cline { 2 - 3 } & Revenue & Expenditure & $\begin{array}{c}\text { Rariance (Surplus/Deficit) } \\
\text { varn }\end{array}$ \\
\hline 2013 & $596,607,458,712.56$ & $588,161,221,865.00$ & $8,446,236,847.56$ \\
2014 & $672,757,348,789.68$ & $668,398,232,931.00$ & $4,359,115,858.68$ \\
2015 & $782,530,360,623.56$ & $782,708,572,912.00$ & $(178,212,288.44)$ \\
2016 & $800,530,284,780.00$ & $800,659,899,520.00$ & $(129,614,740.00)$ \\
2017 & $918,545,076,665.88$ & $888,136,212,304.00$ & $30,408,864,361.88$ \\
2018 & $819,289,952,613.72$ & $887,677,794,370.00$ & $(68,387,841,756.28)$ \\
\hline
\end{tabular}

Source: Data Portal of the Directorate General of Fiscal Balance (MoF)

Based on the table above, it can be seen that the realization of Pasangkayu Regency Government revenue in 2013 to 2017 has always increased, and the revenue decreased by Rp. 
99,255,124,052.16 in 2018. Meanwhile, the realization of Pasangkayu Regency Government expenditure in 2013 to 2017 when viewed from the difference between the total revenue and expenditure of Pasangkayu Regency in 2015, 2016 and 2018 experienced a budget deficit. Meanwhile, in 2013, 2014 and 2017 experienced a surplus. The budget deficit is the difference between the revenue budget and the expenditure budget with a negative value. This means that the revenue budget is less than the expenditure budget [8]. The condition of the realization of revenue and expenditure in Pasangkayu Regency is still considered unstable, particularly seeing the total deficit in 2018 which was quite high, reaching 68,387,841,756.28. Therefore, researchers were interested in examining more deeply by using financial analysis to find out the causes related to the emergence of these problems.

\section{Method of the Study}

This study was a descriptive quantitative study. Descriptive quantitative is a quantitative research method that attempts to collect quantifiable information for statistical analysis of the population and sample of the study [9]. This study was conducted at the Regional Government of Pasangkayu Regency as the object of this study to obtain the required data, specifically quantitative data in the form of numbers consisting of regional financial reports. Sources of data used in this study were obtained through secondary data, specifically in the form of data derived from written materials on the website of the Ministry of Finance of the Republic of Indonesia through the Data Portal of the Directorate General of Fiscal Balance. This study was conducted on the financial data of the Pasangkayu Regency Government in 2013-2018, particularly the data to be investigated, namely the budget and realization of regional revenue and expenditure of Pasangkayu Regency. The analytical tool used in this study was the financial ratio analysis with the following details:

1. Revenue Variance Analysis

This analysis is formulated as follows [6]:

$$
\text { Revenue Variance Analysis = Realization - Revenue Budget }
$$

Budget performance assessment generally uses the variance analysis of the revenue budget. Variance analysis is done by evaluating the difference between budget and revenue realization. The difference in budget can be categorized into two, namely the difference between favorable and unfavorable [6].

2. Fiscal Decentralization Degree Ratio

This ratio is formulated as follows [6]:

$$
\text { Fiscal Decentralization Degree }=\frac{\text { Regional Original Revenue }}{\text { Total Regional Revenue }} \times 100 \%
$$

The Fiscal Decentralization Degree Ratio illustrates the extent of central government intervention in regional development which shows the level of readiness of regional governments in implementing the regional autonomy. The higher the fiscal decentralization degree ratio, the higher the regional financial capability to support the regional autonomy.

Table 2. Financial Capability Level 


\begin{tabular}{ll}
\hline Financial Capability Level & Criteria \\
\hline $\mathbf{0}-\mathbf{1 0}$ & Very Poor \\
$\mathbf{1 0}-\mathbf{2 0}$ & Poor \\
$\mathbf{2 0}-\mathbf{3 0}$ & Fair \\
$\mathbf{3 0}-\mathbf{4 0}$ & Moderate \\
$\mathbf{4 0}-\mathbf{5 0}$ & Good \\
More than 50 & Very Good \\
\hline
\end{tabular}

Source : [10]

3. Regional Independence Ratio

This ratio is formulated as follows [6]:

Regional Independence $=\frac{\text { Regional Original Revenue }}{\text { Total Central Government Assistance,Loans from the Province }} \times 100 \%$

This independence ratio will illustrate the level of regional dependence on external funding sources. The higher the independence ratio, the lower the level of regional dependence on external assistance (particularly the central and provincial governments), and vice versa. The independence ratio also describes the level of community participation in regional development. This means that the higher the independence ratio, the higher the community participation in paying regional taxes and levies, which are the main components of PAD. The relationship patterns and the level of independence ratio can be seen on the following table.

Table 3. Relationship Patterns and Regional Capability Levels

\begin{tabular}{ccc}
\hline Capability & Independence (\%) & Relationship Patterns \\
\hline Very Low & $0-25 \%$ & Instructive \\
Low & $25-50 \%$ & Consultative \\
Moderate & $50-75 \%$ & Participative \\
High & $75-100 \%$ & Delegative \\
\hline Source: $[11]$ & &
\end{tabular}

4. Effectiveness Ratio of Regional Original Revenue

This ratio is formulated as follows [12]:

Effectiveness Ratio of Regional Original Revenue $=\frac{\text { Realization of Regional Original Revenue }}{\text { Target of Regional Original Revenue }} \times 100 \%$

The effectiveness ratio of PAD shows the ability of regional governments to mobilize PAD revenues according to the target. In general, the effectiveness value of PAD can be categorized as follows [6]:

$\begin{array}{ll}\text { Very Effective } & :>100 \% \\ \text { Effective } & : 100 \% \\ \text { Fair Effective } & : 90 \%-99 \% \\ \text { Less Effective } & : 75 \%-89 \% \\ \text { Not Effective } & :<75 \%\end{array}$

5. Expenditute Variance Analysis

This analysis is formulated as follows [6]: 
Expenditure budget performance assessment generally uses budget variance analysis. Variance analysis is done by evaluating the difference between the budget and the realization of expenditure. The difference in budget can be categorized into two, namely the difference between favorable and unfavorable [6].

6. Regional Financial Efficiency Analysis

This analysis is formulated as follows [6]:

$$
\text { Regional Financial Efficiency Analysis }=\frac{\text { Expenditure Realization }}{\text { Revenue Budget }} \times 100 \%
$$

Efficiency means the maximum level of output with a certain input. Efficiency can describe the variance between the amount of costs incurred to obtain revenue with the realization of the revenue received. The Efficiency Ratio Criteria are described as follows:

Table 4. Financial Performance Efficiency Criteria

\begin{tabular}{cc}
\hline Efficiency Criteria & Efficiency Ratio \\
\hline $\mathbf{1 0 0} \%$ and above & Not Efficient \\
$\mathbf{9 0}-\mathbf{1 0 0} \%$ & Less Efficient \\
$\mathbf{8 0}-\mathbf{9 0} \%$ & Fair Efficient \\
$\mathbf{6 0}-\mathbf{8 0} \%$ & Efficient \\
Less than $60 \%$ & Very Efficient \\
\hline
\end{tabular}

Source : [12]

\section{Results of the Study}

The results of the calculation of the financial ratio analysis of Pasangkayu Regency in 2013 - 2018 were measured and explained according to the criteria contained in the literature and previous studies that were related. The detailed explanation can be seen in the following:

\subsection{Revenue Variance Analysis}

The realization of the revenue budget is the minimum amount of revenue that is targeted to be obtained by the regional government. Revenue variance analysis was performed by calculating the difference between the revenue realization and the budgeted amount. The budget difference had been informed in the Budget Realization Report (LRA) presented by the regional government. The regional government is considered to have a good revenue performance if the government is able to earn more than the budgeted amount. Conversely, if the revenue realization is below the budgeted amount, then it cannot be considered as having a good revenue performance. When actual results are better than expected results given, variance is described as Favorable Variance. Meanwhile, when actual results are worse than expected results given, variance is described as Unfavorable Variance. The data of budget and realization of Pasangkayu Regency Revenue in 2013 - 2018 can be seen in the following table: 
Table 5. Revenue Variance Analysis

\begin{tabular}{|c|c|c|c|c|}
\hline Year & Revenue Realization & Revenue Budget & $\begin{array}{l}\text { Revenue } \\
\text { Analysis }\end{array}$ & Criteria \\
\hline 2013 & $489,660,883,889.00$ & $466,332,845,416.00$ & $23,328,038,473.00$ & favourable \\
\hline 2014 & $542,497,822,188.00$ & $523,818,379,625.00$ & $18,679,442,563.00$ & favourable \\
\hline 2015 & $694,863,102,145.00$ & $587,560,622,546.00$ & $107,302,479,599.00$ & favourable \\
\hline 2016 & $799,700,853,131.00$ & $833,824,473,767.00$ & $(34,123,620,636.00)$ & unfavorable \\
\hline 2017 & $858,946,869,587.00$ & $809,554,494,824.00$ & $49,392,374,763.00$ & favourable \\
\hline 2018 & $810,963,003,945.00$ & $783,136,871,049.00$ & $27,826,132,896.00$ & favourable \\
\hline
\end{tabular}

Source: Secondary Data Processed, 2020 (Data Portal of the Directorate General of Fiscal Balance, Ministry of Finance)

Based on the table above, it can be seen in detail the movement of revenue realization, the revenue budget and revenue variance analysis in Pasangkayu Regency for the 2013-2018 fiscal year. In terms of revenue variance in 2013, 2014, 2015, 2017 and 2018, it shows that the amount of realized revenue was greater than the amount of budgeted revenue, this shows the revenue in Pasangkayu Regency Government that has been effective or with favorable criteria. Based on the table above, the movement of realization, budget and analysis of revenue variance of Pasangkayu Regency for the 2016 fiscal year shows the amount of realized revenue which was less than the amount of budgeted revenue, this shows that the revenue in Pasangkayu Regency Government has not been effective or with unfavorable criteria. Regional government is considered to have a good revenue financial performance if it is able to obtain revenue that exceeds the budgeted amount. Conversely, if the revenue realization is below the budgeted amount, then it is considered not having a good revenue financial performance [7]. Based on the above results, the variance analysis in Pasangkayu Regency for the last 6 years has generally shown a good revenue variance criteria.

\subsection{Fiscal Decentralization Degree Ratio Analysis}

The results of calculating the Fiscal Decentralization Degree are recapitulated and measured according to the criteria by using the criteria in the following table:

Table 6. Analysis of Fiscal Decentralization Degree Ratio

\begin{tabular}{ccccc}
\hline Year & $\begin{array}{c}\text { Regional Original } \\
\text { Revenue Realization }\end{array}$ & Revenue Realization & $\begin{array}{c}\text { Fiscal } \\
\text { Decentralization } \\
\text { Degree }\end{array}$ & Criteria \\
\hline 2013 & $15,390,772,754.00$ & $489,660,883,889.00$ & 3.14 & Very Poor \\
2014 & $21,232,571,781.00$ & $542,497,822,188.00$ & 3.91 & Very Poor \\
2015 & $21,897,075,972.00$ & $694,863,102,145.00$ & 3.15 & Very Poor \\
2016 & $27,629,986,869.00$ & $799,700,853,131.00$ & 3.46 & Very Poor \\
2017 & $52,519,268,057.00$ & $858,946,869,587.00$ & 6.11 & Very Poor \\
2018 & $32,207,499,622.00$ & $810,963,003,945.00$ & 3.97 & Very Poor \\
\hline
\end{tabular}

Source: Secondary Data Processed, 2020 (Data Portal of the Directorate General of Fiscal Balance, Ministry of Finance) 
Based on the criteria for the regional capability scale, the assessment from 2013 to 2018 can be considered to have not met the expected results. Based on these results, it can be argued that the authority and responsibility given by the central government to the Pasangkayu Regency Regional Government in terms of managing its resources is still lacking and the level of capability of the Pasangkayu Regency Regional Government in implementing decentralization has also decreased. Fiscal Decentralization Degree is a measure to show the level of authority and responsibility given by the central government to the regional governments to develop the region. The fiscal decentralization degree in this study was measured by using the ratio of PAD to the total regional revenues. The regional original revenue capability to meet the regional expenditure budgets is highly needed in the process of economic development. However, the economic development cannot run smoothly if it only burdens the government. Based on the data above, it can be concluded that the financial capability of Pasangkayu Regency was still in a low condition based on the principle of decentralization. This has led to regional discretion in the budget sector, so that certain limitations in the provision of infrastructure and service delivery to the public are likely to be found. The delegation of some functions to the regions or decentralization is a tool used to achieve a state goal. The purpose of delegating a portion of authority from the central government to local governments is to provide good public services to the community and create political democratization in public decisions [10].

The low degree of decentralization also affects the level of progress of a region. If the degree of decentralization was in the low category, regional development indicators will also tend to be low. Improvements in a good PAD management will greatly assist in the process of accelerating development in Pasangkayu Regency and no longer depend on transfer funds from the central or provincial levels. The regional government of Pasangkayu Regency with a degree of decentralization ratio that was included in the scale of $0-25 \%$ and was still in the very low category indicates that the regional government of Pasangkayu Regency has not been able to carry out the decentralization by optimizing the regional potential to provide better public services, because the contribution of PAD was relatively smaller than with total regional revenue.

\subsection{Regional Independence Ratio Analysis}

The results of the calculation of the independence ratio for the Pasangkayu Regency Government for 2013 to 2018 based on the financial data taken can be seen in the following table 7:

Table 7. Regional Independence Ratio

\begin{tabular}{ccccc}
\hline Year & $\begin{array}{c}\text { Regional Original } \\
\text { Revenue Realization }\end{array}$ & Transfer Revenue & $\begin{array}{c}\text { Regional Financial } \\
\text { Independence Ratio }\end{array}$ & Criteria \\
\hline 2013 & $15,390,772,754.00$ & $42,125,165,814.00$ & 3.48 & Instructive \\
2014 & $21,232,571,781.00$ & $478,745,662,189.00$ & 4.44 & Instructive \\
2015 & $21,897,075,972.00$ & $611,929,514,689.00$ & 3.58 & Instructive \\
2016 & $27,629,986,869.00$ & $715,064,078,831.00$ & 3.86 & Instructive \\
2017 & $52,519,268,057.00$ & $679,982,523,386.00$ & 7.72 & Instructive \\
2018 & $32,207,499,622.00$ & $648,054,274,665.00$ & 4.97 & Instructive \\
\hline
\end{tabular}


Source: Secondary Data Processed, 2020 (Data Portal of the Directorate General of Fiscal Balance, Ministry of Finance)

Based on the table above, it can be seen that the results of the calculation of the regional financial independence ratio in Pasangkayu Regency show a low percentage, because the data presented on the table shows an instructive or very low level which was below the percentage of 25 percent. This could be due to several factors, including regional revenue which varies each year, transfer requests which varies each year, different needs each year, and regional original revenue which fluctuates each year and unexpected expenses. The independence ratio describes the level of dependence of a region on external funding sources. The higher the independence ratio, the lower the level of regional dependence on external assistance (particularly the central and provincial governments), and vice versa. The independence ratio also describes the level of community participation in regional development. This means that the higher the independence ratio, the higher the community participation in paying regional taxes and levies, which are the main components of regional revenue [11]. The condition of the regional government of Pasangkayu Regency when viewed from the calculation of the independence ratio was still in a very low category with a pattern of instructive relationships for 2013 - 2018 on a scale of 0 $25 \%$, which means that the role of the central government is still more dominant than the regional independence itself. Regional government was not yet capable enough to self-finance government activities, development and services.

\subsection{Effectiveness Ratio Analysis of Regional Original Revenue}

The results of the calculation of the PAD effectiveness ratio for the Pasangkayu Regency Government for 2013 to 2018 based on the data obtained can be seen in the following table:

Table 8. Effectiveness Ratio Analysis of Regional Original Revenue

\begin{tabular}{ccccc}
\hline Year & $\begin{array}{c}\text { Regional Original } \\
\text { Revenue Realization }\end{array}$ & Target of PAD & $\begin{array}{c}\text { Effectiveness } \\
\text { Ratio of PAD }\end{array}$ & Criteria \\
\hline 2013 & $15,390,772,754.00$ & $8,233,088,478.00$ & 186.94 & Very Effective \\
2014 & $21,232,571,781.00$ & $14,117,948,929.00$ & 150.39 & Very Effective \\
2015 & $21,897,075,972.00$ & $21,940,960,324.00$ & 99.80 & Less Effective \\
2016 & $27,629,986,869.00$ & $23,710,914,973.00$ & 116.53 & Very Effective \\
2017 & $52,519,268,057.00$ & $27,399,910,416.00$ & 191.68 & Very Effective \\
2018 & $32,207,499,622.00$ & $29,483,819,641.00$ & 109.24 & Very Effective \\
\hline
\end{tabular}

Source: Secondary Data Processed, 2020 (Data Portal of the Directorate General of Fiscal Balance, Ministry of Finance)

Based on the table above, it can be seen that the results of the calculation of the effectiveness ratio of PAD in Pasangkayu Regency show that the percentage was not stable due to the fluctuating data. This is due to the realization factor in each element of PAD which varies from year to year. Referring to this matter, it can be concluded that the level of effectiveness of PAD in Pasangkayu Regency from 2013, 2014, 2016, 2017 and 2018 has shown effective criteria with a percentage of above 100 percent. Meanwhile, in 2015, the effectiveness ratio of PAD was in the less effective criteria. So it can be concluded that the overall results have described the effectiveness of utilizing the PAD. The effectiveness ratio describes the ability of 
a region to realize the planned PAD compared to the target set based on the real potential in an area. The higher the ratio of effectiveness, the better the performance of regional governments. The PAD effectiveness ratio was calculated by comparing the realization of PAD revenue with the PAD revenue target (budgeted). The PAD effectiveness ratio shows how the ability of regional governments to mobilize the $\mathrm{PAD}$ revenue according to the target in one fiscal year.

\subsection{Expenditure Variance Analysis}

Expenditure budget variance analysis is the difference between expenditure realization and expenditure budget. The following calculation shows the variance of the expenditure budget from 2013 to 2018.

Table 9. Expenditure Variance Analysis

\begin{tabular}{ccccc}
\hline Year & $\begin{array}{c}\text { Expenditure } \\
\text { Realization }\end{array}$ & Expenditure Budget & $\begin{array}{c}\text { Expenditure } \\
\text { Variance Analysis }\end{array}$ & Criteria \\
\hline 2013 & $481,604,349,137.00$ & $494,226,239,473.00$ & $(12,621,890,336.00)$ & unfavorable \\
2014 & $565,249,797,481.00$ & $561,688,168,000.00$ & $3,561,629,481.00$ & favourable \\
2015 & $725,289,179,086.00$ & $618,396,431,649.00$ & $106,892,747,437.00$ & favourable \\
2016 & $817,117,557,558.00$ & $867,050,157,637.00$ & $(49,932,600,079.00)$ & unfavorable \\
2017 & $844,377,134,204.00$ & $824,771,356,824.00$ & $19,605,777,380.00$ & favourable \\
2018 & $808,616,170,490.00$ & $800,636,871,049.00$ & $7,979,299,441.00$ & favourable \\
\hline
\end{tabular}

Source: Secondary Data Processed, 2020 (Data Portal of the Directorate General of Fiscal Balance, Ministry of Finance)

The expenditure variance analysis is the difference between the expenditure realization and the expenditure budget. Based on the table above, it can be said that the amount of expenditure realization in Pasangkayu Regency Government in 2014, 2015, 2017 and 2018 was greater than the amount budgeted by favorable criteria. Meanwhile, in 2013 and 2016, the expenditure realization was smaller than the expenditure budget with unfavorable criteria. Regarding to the results, it can be concluded that the expenditure variance analysis of Pasangkayu Regency from 2013 to 2018 was largely favorable according to the criteria that have been determined in theory. However, Pasangkayu Regency is required to continuously conduct a review of this expenditure budgeting, because the expenditure that is not budgeted maximally will have an effect on regional revenue in a period.

\subsection{Regional Financial Efficiency Analysis}

The results of the calculation of the regional financial efficiency ratio for the Pasangkayu Regency Government for 2013 to 2018 based on the data obtained can be seen in the following table:

Table 10. Regional Financial Efficiency Analysis

\begin{tabular}{ccccc}
\hline Year & $\begin{array}{c}\text { Expenditure } \\
\text { Realization }\end{array}$ & Revenue Budget & $\begin{array}{c}\text { Regional Financial } \\
\text { Efficiency Ratio }\end{array}$ & Criteria \\
\hline 2013 & $481,604,349,137.00$ & $466,332,845,416.00$ & 103.27 & Not Efficient
\end{tabular}




\begin{tabular}{ccccc}
\hline Year & $\begin{array}{c}\text { Expenditure } \\
\text { Realization }\end{array}$ & Revenue Budget & $\begin{array}{c}\text { Regional Financial } \\
\text { Efficiency Ratio }\end{array}$ & Criteria \\
\hline 2014 & $565,249,797,481.00$ & $523,818,379,625.00$ & 107.91 & Not Efficient \\
2015 & $725,289,179,086.00$ & $587,560,622,546.00$ & 123.44 & Not Efficient \\
2016 & $817,117,557,558.00$ & $833,824,473,767.00$ & 98.00 & Less Efficient \\
2017 & $844,377,134,204.00$ & $809,554,494,824.00$ & 104.30 & Not Efficient \\
2018 & $808,616,170,490.00$ & $783,136,871,049.00$ & 103.25 & Not Efficient \\
\hline
\end{tabular}

Source: Secondary Data Processed, 2020 (Data Portal of the Directorate General of Fiscal Balance, Ministry of Finance)

The table above describes the results of calculating the financial efficiency ratio for 2013 to 2018. Referring to the results, the average level of efficiency of regional financial management in Pasangkayu Regency during the 2013, 2014, 2015, 2017 and 2018 fiscal years had less efficient results, while the results for the year 2016 shows results with inefficient criteria. The existence of inefficient criteria was caused by the lack of regional revenue when compared to the expenditure. The unplanned expenditure allocations and ineffective management of revenue sources was found in 2013 to 2018. Based on the results obtained in this study, it was also found that the effectiveness level of Regional financial management in Pasangkayu Regency from 2013 to 2018 has not been going well or is very inefficient. A regional government needs funds to carry out development, where the financing comes from the APBD. In line with the existence of regional autonomy, the regions must manage their regional finances properly. Therefore, financial management that is carried out efficiently must be carried out optimally, because this will be related to the target and realization of regional revenues. If the financial management is efficient, this means that a guarantee for the availability of development funds has been found, and if the management is still not efficient, then it requires an encouragement so that its management will be better and will guarantee the availability of funds for development in an area. Regarding to that matter, this will be able to guarantee the regional financial independence which will get better in the future.

\section{Discussion}

The ability of regional governments to manage finances is reflected in the Regional Revenue and Expenditure Budget (APBD), which describes the ability of regional governments to finance development tasks, as well as equity and justice by developing all the potentials of each region. One of the main characteristics of a region being able to implement regional autonomy lies in the regional financial capability to finance the administration of its regional government with the decreasing level of dependence on the central government and it is expected that Regional Original Revenue (PAD) should be the largest part in mobilizing regional government administration funds.

Based on the results of the financial analysis above, the majority of the results of the financial analysis were still very low and need to be corrected and evaluated by the Pasangkayu Regency Government. The first result was concerning to the fiscal decentralization degree which was still below 10 percent or had less criteria from 2013 to 2018 . Fiscal decentralization is directly related to the government's relationship in the revenue and expenditure of public funds between higher levels of government and the government below. The low level of fiscal 
decentralization will indirectly affect the achievement of regional autonomy implementation. Fiscal decentralization and the implementation of regional autonomy will increase the authority of regional governments to increase revenue and carry out an allocative function in setting regional development priorities. The results above also show the low level of financial independence of Pasangkayu Regency from 2013 to 2018, which was still below 25 percent. This indicated that the dependence on central government assistance or loans was still high. The ratio of regional financial independence or fiscal autonomy showed the ability of regional governments to self-finance government activities, development, and services to people who have paid taxes and levies as a source of regional revenue. Moreover, the Pasangkayu Regency Government was still inefficient based on the Regional Financial Efficiency Analysis for 2013 to 2018 .

Although the results obtained were still not optimal based on financial ratio analysis, there were still local dynamics and efforts to improve the financial capability and encourage the regional economic potential through the increased PAD and investment based on their potential. Some of these efforts have actually resulted in access to policies for increasing the PAD that are counterproductive to increased investment. In addition, the trend of regional original revenue in Pasangkayu Regency tends to increase every year. This indicated that improvements and the management of economic resources and regional potential are gradually carried out.

Based on the results of interviews at the location of this study, Pasangkayu Regency has the potential to grow into a large regency with regional potential management. Through the potential possessed by various sectors, especially agriculture, plantation and livestock, tourism and other sectors, with optimism and hard work in the future, pasangkayu ensures to become an agropolitan or agrosmart (in pasangkayu), namely the development of a technology-based agricultural sector. Agrosmart or agropolitan is a transformation from the previous program, namely sanggayu smart which has been designed in such a way that it is expected to become a prestigious program in pursuing the accelerated development target of Pasangkayu Regency. Pasangkayu has an oil palm plantation with a high enough productivity. The next leading potential that contributes to regional revenue is the cultivation of vannamei shrimp ponds which continues to be developed both in quality and quantity. These potentials will later become an item for improving the financial performance of Pasangkayu Regency in the future. By utilizing the existing potential, the financial performance will indirectly increase.

\section{Conclusion}

Based on the results of the discussion that had been carried out, it can be concluded that the Revenue Variance Analysis carried out in terms of revenue in 2013, 2014, 2015, 2017 and 2018 showed that the amount of realized revenue was greater than the budgeted amount. This showed that the revenue in Pasangkayu Regency Government has been effective or with favorable criteria. Meanwhile, the 2016 fiscal year showed that the amount of realized revenue was smaller than the budgeted amount, this showed that the revenue in the Pasangkayu Regency Government has not been effective or with unfavorable criteria. The ratio of fiscal decentralization degrees to the regional government of Pasangkayu Regency in 2013 to 2018 tended to show less than optimal results, which were still below 10 percent. Based on the scale criteria for the assessment of the regional capability in 2013 to 2018, the financial capability of Pasangkayu Regency was considered to be very lacking. 
The calculation of the regional financial independence ratio of Pasangkayu Regency from 2013 to 2018 was still at an instructive or low level which was below the 25 percent criterion. Based on the results of the calculation of the effectiveness of PAD financial management in 2013-2018, it can be seen that the level of effectiveness of PAD management carried out by regional governments ranges from $99.00 \%$ to $157.0 \%$. This achievement figure indicated that the level of effectiveness of the Pasangkayu Regency government has shown the effective criteria with a percentage above 100 percent. Analysis of the expenditure variance based on the results above can be said that the amount of realized expenditure in Pasangkayu Regency in 2014, 2015, 2017, 2018 was greater than the amount budgeted by favorable criteria. Meanwhile, in 2013 and 2016, the expenditure realization was smaller than the expenditure budget with unfavorable criteria. While referring to the financial efficiency ratio for 2013 to 2018 as a whole, the average level of efficiency of regional financial management in Pasangkayu Regency during the 2016 fiscal year was less efficient, while the results in 2013, 2014, 2015, 2016, 2017 and 2018, were inefficient criteria.

\section{References}

[1] Meilida, P.Sarwono, A. E.and Astuti, D. S. P.: Pengukuran Kinerja Keuangan Pada Pemerintah Daerah (Studi Kasus Di Kabupaten Kotawaringin Timur), J. Akunt. dan Sist. Teknol. Inf., vol. 15, no. 3, (2020).

[2] Efendi, D. and Wuryanti, S.: Analisis Perkembangan Kemampuan Keuangan Daerah Dalam Mendukung Pelaksanaan OTODA Di Kabupaten Nganjuk, in Prosiding Seminar Nasional \& Internasional, ( 2011), vol. 1, no. 1.

[3] Kamaroellah, R. A.: Analisis Tingkat Kemampuan Keuangan Daerah Dalam Mendukung Pelaksanaan Otonomi Daerah, NUANSA J. Penelit. Ilmu Sos. dan Keagamaan Islam, vol. 14, no. 1, pp. 123-138, (2017).

[4] Wahyudi, M.: Kinerja Keuangan Pemerintah Daerah Dalam Era Otonomi Daerah (Studi Kasus Pemerintah Daerah Kota Magelang), J. RAK (Riset Akunt. Keuangan), vol. 2, no. 2, pp. 25-32, (2018).

[5] Machmud, M.: Analisis Kinerja Keuangan Daerah Di Provinsi Sulawesi Utara Tahun $2007-$ 2012, J. Berk. Ilm. efisiensi, vol. 14, no. 2, (2014).

[6] Mahmudi:Analisis Laporan Keuangan Pemerintah Daerah. Yogyakarta: UPP STIM YKPN, (2016).

[7] Ramadani, R. F.: Analisis Kinerja Anggaran Dan Realisasi Pendapatan Dan Belanja Daerah Permerintah Kota Samarinda, Ekonomia, vol. 5, no. 3, pp. 327-345, (2017).

[8] Prihatiningsih, A. and HM, S. H. M. S.: Defisit Anggaran Dan Implikasinya Terhadap Perkembangan Ekonomi Dan Kinerja Keuangan Kabupaten Tebo, J. Perspekt. Pembiayaan dan Pembang. Drh., vol. 1, no. 2, pp. 97-108, (2013).

[9] Sugiyono:Metode Penelitian Pendidikan Pendekatan Kuantitatif, Kualitatif, dan R\&D. Bandung: Alfabeta., (2013).

[10] Rofingatun, S. and Kreuta, B.: Analisis Kemampuan Keuangan Daerah Pemerintah Kabupaten Jayapura, KEUDA J. Kaji. Ekon. DAN Keuang. Drh., vol. 2, no. 3, (2017).

[11] Ulum, M. D.:Audit Sektor Publik. (2012).

[12] Mahsun, M.Sulistiyowati, F.and Purwanugraha, A.: Akuntansi Sektor Publik Edisi Ketiga, BPFE Yogyakarta, (2011). 